\title{
A Fluted Paleo-Indian Projectile Point From Belize, Central America
}

Thomas R. Hester

Center for Archaeological Research

Thomas C. Kelly

Center for Archaeological Research

Giancarlo Ligabue

Center for Archaeological Research

Follow this and additional works at: https://scholarworks.sfasu.edu/ita

Part of the American Material Culture Commons, Archaeological Anthropology Commons, Environmental Studies Commons, Other American Studies Commons, Other Arts and Humanities Commons, Other History of Art, Architecture, and Archaeology Commons, and the United States History Commons

Tell us how this article helped you.

This Article is brought to you for free and open access by the Center for Regional Heritage Research at SFA ScholarWorks. It has been accepted for inclusion in Index of Texas Archaeology: Open Access Gray Literature from the Lone Star State by an authorized editor of SFA ScholarWorks. For more information, please contact cdsscholarworks@sfasu.edu. 


\section{A Fluted Paleo-Indian Projectile Point From Belize, Central America}

Creative Commons License

(c) (i) (8)

This work is licensed under a Creative Commons Attribution-NonCommercial 4.0 International License 


\title{
A FLUTED PALEO-INDIAN PROJECTILE POINT \\ FROM BELIZE, CENTRAL AMERICA
}

Thomas R. Hester, Thomas C. Kel1y, and Giancarlo Ligabue

Center for Archaeological Research The University of Texas at San Antonio Working Papers in Archaeology, No. 1

\author{
March 1981
}





\author{
Center for Archaeological Research \\ The University of Texas at San Antonio \\ San Antonio, Texas \\ 78285-0658 \\ Thomas R. Hester, Director
}

Working Papers Series

No. 1 A Fluted Paleo-Indian Projectile Point from Belize Central America. By Thomas R. Hester. Thomas C. Kelly, and Giancarlo Ligabue, 1981, third printing, 1983. Photocopy reprint $\$ 1.50$ $(\$ .08)+\$ 1.00 \mathrm{P} \& H$.

No. 2 Early Evidence of Maya Hieroglyphic Writing at Kichpanha, Belize. By Eric C. Gibson, Les 1 ie C. Shaw, and Daniel R. Finamore, 1986. $\$ 3.00(\$ .17)+\$ 1.50 \mathrm{P} \& \mathrm{H}$.

No: 3 An Ancient Maya Hafted Stone Tool from Northern Belize. By Harry J. Shafer and Thomas R. Hester, 1986. \$3.00 (\$.17) +\$1.50 P\&H.

Other Mesoamerican publications available through the Center for Archaeological Research are:

The Colha Project, 1979: A Collection of Interim Papers. Edited by Thomas R. Hester, 1979. Third printing, 1983. \$8.00 (\$.44) $+\$ 2.00 \mathrm{P \& H}$.

The Colha Project: Second Season, $1980^{\circ}$ Interim Report. Edited by Thomas R. Hester, Jack D. Eaton, and.Harry J. Shafer, 1980. Fourth printing, 1985. \$18.00 (\$.99) +\$3.00 P\&H.

Archaeology at Colha, Belize: The 1981 Interim Report Edited by Thomas R. Hester, Harry J. Shafer, and Jack D. Eaton, 1982. Şecond printing, 1983. \$17.00 (\$.94) +\$2.00 P\&H.

Rio Azul Project Reports Number 1, Final 1983 Report Edited by R. E. W. Adams, 1984. \$4.00 $(\$ .22)+\$ 1.50 \mathrm{P} \& \mathrm{H}$.

Rio Azu 1 Reports Number 2. The 1984 Season. Edited by R. E. W. Adams, 1986. \$15.00 $\$ .66)+\$ 2.00 \mathrm{P} \& \mathrm{H}$.

Also a limited number of the following volume (hardcover, with jacket; more than 100 color plates, with English titles):

Colha e i Maya Dei Bassipiani. Edited by T. R. Hester, G. Ligabue, S. Salvatori, and M. Sartor. Errizzo Editrice, Venice. 1983, 241 P. $\$ 35.00$, postage and handling included. 



\section{A FLUTED PAIEO-INDIAN PROJECTIIE POINT FROM BELIZE, CENTRAL AMERICA}

Thomas R. Hester, Thomas C. Kelly, and Giancarlo Ligabue

While much archaeological research has focussed on ancient Maya cultures in the lowland jungles and coastal region of Belize (Palacio 1976; Graham 1980), it has been only recently that the remains of very early Maya settlements, and indeed of pre-Maya occupations, have been found. Hammond et al. (1979) have defined the Early Preclassic Swasey manifestation at the site of Cuello, dating to ca. 1900 B.C., and representing a sedentary agricultural society. Most notable of the pre-Maya (preceramic) investigations is the Belize Archaic Archaeological Reconnaissance (BAAR) directed by Richard S. MacNeish (MacNeish, Wilkerson and Nelken-Terner 1980). They have proposed a very tenative Archaic sequence consisting of five major time periods (and artifact assemblages) spanning the period from ca. 9,000-2,500 B.C. Dating is tenuous for each period, and thus far, no radiocarbon dates are available. Two major sites, Lowe Ranch and Sand Hill, originally recorded by the Colha Project (Hester, Eaton and Shafer 1980) have been further studied by MacNeish and his colleagues.

The Colha Project, initiated in 1979, has been oriented toward the study of the lithic technology of Maya culture from Early Preclassic through Early Postclassic times. The large lithic workshops at the site of Colha (cf. Shafer and Hester 1979), have produced evidence of stone tool mass production in the Late Preclassic, Late Classic and Early Postclassic periods. Additional data on the lithic technology of Middle and probably Early Preclassic periods comes from middens and construction fill deposits at Colha (Early Preclassic lithics are documented at Cuello; cf. Hammond et al. 1979; Shafer, et al., ms.)

Part of the research design of the Colha Project (Hester 1979; Hester, Eaton and Shafer 1980) has involved three seasons of regional survey within the chert-bearing zone in central and northern Belize, as defined by Wright et al. (1959). Major objectives of the survey are to search for lithic workshops and other chert tool production sites (to help set the massive industries at Colha in perspective) and to better determine the distribution of tools produced at, and exported from, Colha (cf. Kelly 1980). Further, the survey has sought to establish and define the nature of lithic tool forms aside from those made at Colha and to map the occurrence of various types and qualities of chert within the zone mapped by Wright et al. (1959).

However, during the course of the survey, all observed sites are being recorded as much of the region within which the survey team has operated has not been previously examined by archaeologists. Thus, in addition to lithic scatters, workshops, and debitage mounds, the survey team has also recorded house mounds, mound groups, settlement areas, and other types of sites. Many of the lithic sites exhibit quarrying and chert-working activities ranging from probable preceramic times well into the various periods of Maya culture (e.g., at Sand Hill and Lowe Ranch; Hester, Shafer and Kelly 1980; Shafer, Hester and Kelly 1980). 
In February, 1981, in the midst of our 1981 season, the regional survey team, headed by Kelly, conducted field work in the southern part of the chert-bearing zone (Fig. 1). Near the town of Ladyville, north of Belize City, the survey team recorded a site (Ladyville 非) with an abundance of exposed surface lithics. The lithics were, in general, heavily. patinated and were not particularly distinctive as to form or type. Some appeared to be distributed into workshops or specific tool-making (or tool-use) areas. There are some tool forms and other materials that resemble the Sand Hill and Lowe Ranch materials (MacNeish; Wilkerson and Nelken-Terner 1980; Shafer, Hester and Kelly 1980; Hester, Shafer and Kelly 1980). We will report on these at a later date.

During the examination of the surface materials at Ladyville 非, a fluted lanceolate point was found (Fig. 2). It is quite different from the Archaic materials that MacNeish's studies have recorded. Further, it appears to be the first fluted point of Paleo-Indian style to be reported from the coastal lowlands, and certainly the first from Belize.

The Ladyville fluted point is finely flaked. The chert is patinated to a white, and in places yellow-white, color. It is $9.16 \mathrm{~cm}$ long, $3.59 \mathrm{~cm}$ wide, and has a maximum thickness of $.83 \mathrm{~cm}$. Weight is 29.7 gm. Basal dulling present on the lateral edges and on the remaining basal corner (Fig. 2). On one face, the base has been fluted, with a scar $2.0 \mathrm{~cm}$ long and $1.4 \mathrm{~cm}$ wide; a secondary thinning flake was also removed (Fig. 2, right). On the other face, a slightly larger flute, $2.5 \mathrm{~cm}$ long and $1.5 \mathrm{~cm}$ wide, is present (Fig. 2, left).

The basal portion of the point is slightly constricted, although this may be attributed to the heavy lateral edge grinding. The technology and morphology of this fluted point, and its occurrence in an aceramic, apparently non-Maya context, suggests to us that it is of Paleo-Indian age.

Fluted points are reported from various areas of northern Mesoamerica (cf. Aveleyra Arroyo de Anda 1964), from the Highlands of Guatemala (Coe 1960; Gruhn and Bryan 1977; Brown 1980), from other highland areas in Central America (Sander 1959, 1964; Snarkis 1977; Swavger and Mayer-Oakes 1952), and at numerous localities in South America (see Lynch 1978; Heizer and Hester 1978). In South America, there are typological problems involving "fishtail" fluted points (also known as Magellan I or El Inga points; cf. Mayer-Oakes and Bell 1960; Mayer-Oakes 1963; Willey 1971: 44-45; Lynch 1978) and lanceolate points technologically reminiscent of the Clovis type of North America .

Clovis-like points are documented from Costa Rica (Snarkis 1977). One of these specimens, from the site of Turrialba, seems rather similar to the Ladyville point (Snarkis 1977: Fig. 2, d).

It is our present opinion, in briefly reviewing the fluted point data from North, Central and South America, that the Ladyville specimen should be probably included within the Clovis type. Obviously, such a typological evaluation could be better tested if we had 

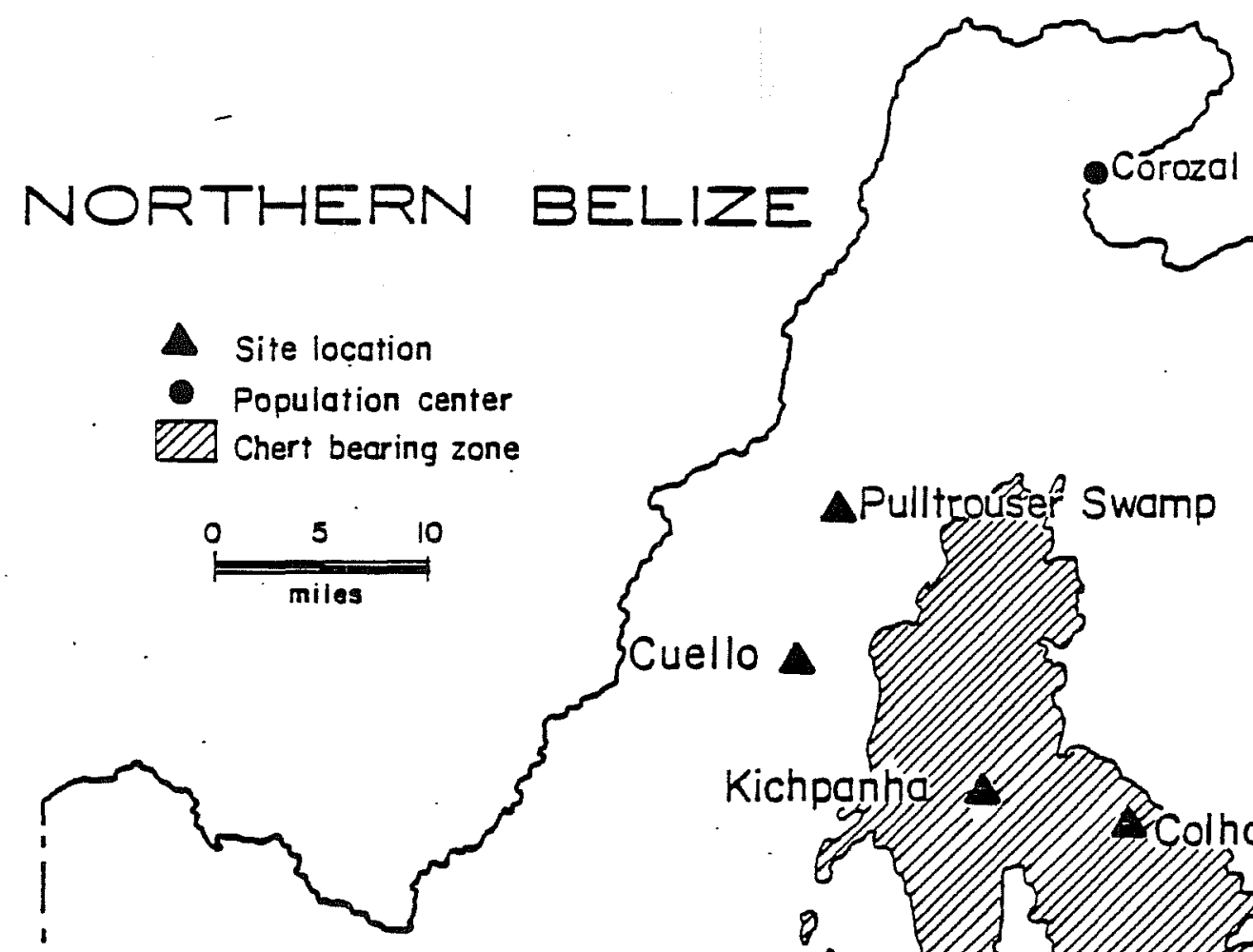
additional specimens of this form from the Maya lowlands. As it now stands, the specimen reported here is, as far as we know, the first fluted lanceolate point from the region. That it occurs is not surprising, as MacNeish has already found, in his 1980 season, many sites. that are of Archaic age. But, the discovery of this specimen indicates new potential for further expanding the known cultural sequence in Belize. If we are correct in linking the Ladyville specimen to the Clovis type, it would date to ca. 9,200 B.C. (cf. Haynes 1967), and would make it the earliest documented artifact from Belize.

The Ladyville fluted point will be registered, at the end of our 1981 season, with the Department of Archaeology, Belmopan, and will become part of the permanent collection of the department. Other than to put this specimen on record (and, later, the other lithics found in the survey), no extensive investigations are planned by the Colha Project at Ladyville 非: We will, under the terms of our Antiquities Permit (70/2/81) and within the scope of our research design, do very limited testing to ascertain if any of the extensive lithic materials can be linked (as is the case at the Sand Hill locality; Shafer, Hester and Kelly 1980) to Maya Iithic workshop activities.

\section{REFERENCES CITED}

Aveleyra Arroyo de Anda, L.

1964 The Primitive Hunters. In, R. C. West, ed., Natural Environment and Early Cultures, Handbook of Middle American Indians 1:384-412.

Brown, K. M.

1980 A Brief Report on Paleoindian-Archaic Occupations in the Quiche Basin, Guatamela. American Antiquity 45(2) :313-324.

Coe, M. D.

1960 A Fluted Point from Highland Guatemala. American Antiquity $25(3): 412-413$.

Graham, E. A.

1980 The Maya and Belize. Cubola Productions, Benque Viejo

Gruhn, R. and A. L. Bryan

1977 Los Tapiales: A Paleo Indian Campsite in the Guatemalan Highlands. Proceedings, American Philosophical Society $121(3): 235-27 \overline{3}$. 


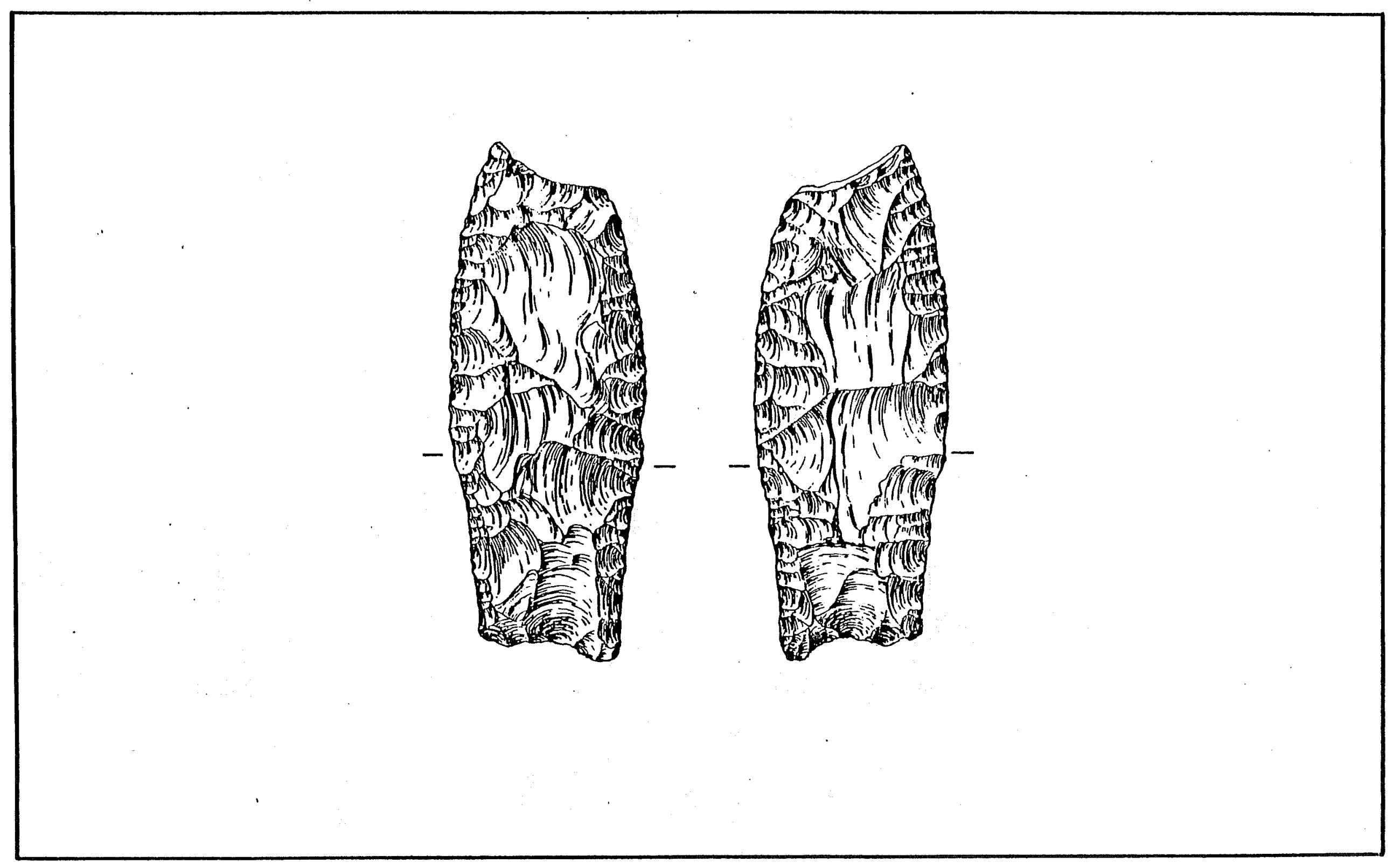

F1gure 2. Fluted Point from Ladyvile S1te, Belize. Both sides are shown at actual size. Hortzontal 1ines indicate extent of duling of lateral edges. 
Hammond, N., D. Pring, R. Wilk, S. Donaghey, F. Saul, E. Wing, A. Miller and L. Feldman

1979 The Earliest Lowland Maya? Definition of the Swasey Phase. American Antiquity 44(1):92-110.

Haynes, C. V.

1967 Carbon-14 Dates and Early Man in the New World. In P.S. Martin and H. E. Wright, Jr., eds., Pleistocene Extinctions: The Search for a Cause: $267-\overline{287 . ~ Y a l e}$ University Press, New Haven.

Heizer, R. F. and T. R. Hester

1978 Migrazioni e Popolamento del Nuovo Mondo. In Alto Orinoco, Indios e Ambiente: 77-90. Erizzo Editrice, Venezia.

Hester, T. R. ed.

1979 The Colha Project, 1979: A Collection of Interim Papers. Center for Archaeological Research, The University of Texas at San Antonio.

Hester, T. R., J. D. Eaton, and H. J. Shafer, eds.

1980 The Colha Project, Second Season, 1980 Interim Report. Center for Archaeological Research, The University of Texas at San Antonio and Centro Studi e Ricerche Ligabue, Venezia. San Antonio.

Hester, T. R., H. J. Shafer and T. C. Kelly

1980 A Preliminary Note on Artifacts from the Lowe Ranch: A Preceramic Site in Belize. In T. R., Hester, J.'D. Eaton, and H. J. Shafer, eds., The Colha Project, Second Season, 1980 Interim Report: 229-232. Center for Archaeological Research, The University of Texas at San Antonio and Centro Studi e Ricerche Ligabue, Venezia. San Antonio.

Kelly, T. C.

1980 The Colha Regional Survey. In I. R. Hester, J. D. Eaton, and H. J. Shafer, eds., The Colha Project, Second Season, 1980 Interim Reports: 51-70. Center for Archaeological Research, The University of Texas at San Antonio and Centro Studi e Ricerche Ligabue, Venezia. San Antonio.

Lynch, T. F.

1978 The South American Paleo-Indians. In J. D. Jennings, ed., Ancient Native Americans: 455-490. W. H. Freeman, San Francisco. 
MacNeish, R. S., S. J. K. Wilkerson, and A. Nelken-Terner

1980 First Annual Report of the Belize Archaic Archaeological Reconnaissance. Robert S. Peabody Foundation for Archaeology, Phillips Academy, Andover, Massachusetts.

Mayer-Oakes, w. J.

1963 Early Man in the Andes. Scientific American 208 (5): 116-128.

Mayer-Oakes, W. J. and R. E. Bell

1960 Early Man Site Found in Highland Ecuador. Science 131: $1805-1806$.

Palacio, J. 0.

1976 Aechaeology in Belize. Cubola Productions, Benque Viejo del Carmen, Belize.

Sander, D.

1959 Fluted Points from Madden Lake. Panama Archaeologist 2(1).

1964 . Iithic Material from Panama: Fluted Points from Madden Lake. XXXV Congreso Internacional de Americanistas, Actas y Memorias I: 183-192. Mexico City.

Shafer, H. J. and T. R. Hester

1979 Lithic Research at Colha: An Overview. In T. R. Hester, ed., The Colha Project, 1979: A Collection of Interim Papers: 18-27. Center for Archaeological Research, The University of Texas at San Antonio.

Shafer, H. J., T. R. Hester, and T. C. Relly

1980 Notes on the Sand Hill Site. In T. R. Hester, J. D. Eaton, and H. J. Shafer, eds., The Colha Project Second Season, 1980 Interim Report: $233-240$. Center for Archaeological Research, The University of Texas at San Antonio and Centro Studi e Ricerche Ligabue, Venezia. San Antonio.

Shafer, H. J., T. R. Hester, T. C. Kelly, and N. Hammond

ms. An Analysis of Formative Period Lithic Artifacts from the 1976 Excavations at Cuello, Belize. Manuscript on file, Center for Archaeological Research, The University of Texas at San Antonio. 
Snarkis, M. J.

1977 Turrialba (9-FG-R), Un Sitio Paleoindio en el Este de Costa Rica. Vínculos 3(1-2):13-25.

Swauger, J. I. and W. J. Mayer-Oakes

1952 A Fluted Point from Costa Rica. American Antiquity 17 : 264-265.

Willey G. R.

1971 An Introduction to American Archaeology. Vol. 2, South America. Prentice-Hall, Inc., Englewood Cliffs, N. J.

Wright, A. C. S., D. H. Romney, R. H. Arbuckle, and V. E. Vial

1959 Land in British Honduras. Colonial Research Report 24. Her Majesty's Stationery Office, London. 